\title{
Susceptibility of Gossypium mustelinum Populations to the Main Cotton Diseases in Brazil
}

\author{
Ivandilson Pessoa Pinto de Menezes ${ }^{1,2}$, Fernanda Amato Gaiotto ${ }^{2}$, Nelson Dias Suassuna ${ }^{3}$, \\ Lúcia Vieira Hoffmann ${ }^{3} \&$ Paulo Augusto Vianna Barroso ${ }^{3}$ \\ ${ }^{1}$ Instituto Federal Goiano, Urutaí, Goiás, Brazil \\ ${ }^{2}$ Universidade Estadual de Santa Cruz, Ilhéus, Bahia, Brazil \\ ${ }^{3}$ Embrapa Algodão, Núcleo do Cerrado, Santo Antônio de Goiás, Goiás, Brazil \\ Correspondence: Instituto Federal Goiano, Urutaí, Goiás, Brazil. Tel: 64-3465-1900, ex. 2010. E-mail: \\ ivan.menezes@ifgoiano.edu.br
}

Received: December 11, 2013 Accepted: January 8, 2014 Online Published: February 15, 2014

doi:10.5539/jas.v6n3p39

URL: http://dx.doi.org/10.5539/jas.v6n3p39

\begin{abstract}
The present study was conducted in five Gossypium mustelinum populations that were phenotyped and genotyped to quantify their resistance to the major diseases that affect cultivated cotton (G. hirsutum) in Brazil. Four $G$. mustelinum populations, in addition to genotypes of G. hirsutum and G. barbadense (resistant or susceptible controls), were phenotyped for resistance to cotton blue disease, angular leaf spot, common mosaic and ramulose. Artificial inoculation of cotton plants with causative agents of cotton blue disease, angular leaf spot and ramulose, as well as those naturally infested with common mosaic virus, showed that all G. mustelinum accessions were susceptible to every disease studied. Four microsatellite markers linked to disease resistance genes for cotton blue disease, angular leaf spot and root-knot nematodes (Meloidogyne spp.) in G. hirsutum were used for genotyping of the five populations. The markers amplified different alleles from those associated with resistance genes in cultivated cotton, revealing polymorphisms different from reported cases of G. hirsutum resistance. The susceptibility to all diseases studied may represent a phytosanitary risk for the in situ conservation of natural $G$. mustelinum populations.
\end{abstract}

Keywords: in situ conservation, SSR marker, natural populations, wild cotton

\section{Introduction}

In situ conservation of landraces or wild relatives of cultivated plants can be hindered if crops are cultivated near these populations. One possible interference is the genetic mischaracterization of wild populations due to gene flow (Groot et al., 2003). This possibility has been discussed with greater emphasis after the commercial release of genetically modified cultivars (Ellstrand et al., 1999; Darmency, 2008). Despite the importance of gene flow, other factors may render in situ conservation more complex independently of whether the cultivated genotypes are genetically modified or not.

Commercial crops or other exotic plants introduced by man can trigger outbreaks of pests and diseases that, depending on the distance, can affect related wild species or local varieties (landraces). The impact on genotypes previously present in the region depends on several factors, including the level of genetic resistance to diseases in cultivated and wild genotypes (Alexander, 2010). The understanding of epidemics in commercial crops has been widely discussed in recent years (Anderson et al., 2004; Fisher et al., 2012); however, little is known about the levels of resistance in wild populations. In some pathosystems, the causative agent of the disease has a wide range of hosts, including related species. In such cases, co-cultivation of susceptible species may have a negative impact on natural populations.

There are well-reported cases where populations of native species have been negatively affected by the introduction of cultivated genotypes, such as Ulnus spp. (North America, Europe and Southeast Asia), Castanea dentata (Western U.S.), Eucalyptus (Australia) and Nassela pulchra (California) (Gilbert, 2002; Anderson et al., 2004). Among native grasses in California, for example, an increased incidence of pathogens due to coexistence with cultivated exotic grasses caused a reduction in their reproductive performance, reducing the number of individuals descended from wild populations (Malmstrom et al., 2005). 
Wild populations and landraces comprise a dynamic germplasm from the point of view of variability because they are subjected to all evolutionary factors. If a new, very aggressive evolutionary agent is introduced into the environment, the selection resulting from the adaptation of populations to this new agent can reduce their genetic basis, jeopardizing the conservation of the variability not associated with the new agent and preventing proper in situ conservation. Brazil is an important center of origin and diversity of wild and cultivated populations, including several species of Manihot (Fukuda et al., 2005), Passiflora (Cervi, 2006), Zea mays L. (Carvalho et al., 2002), Phaseolus vulgaris (Burle et al., 2010), G. hirsutum var. marie galante (Menezes et al., 2010), Oryza glumaepatula (Brondani et al., 2005) and Gossypium mustelinum (Barroso et al., 2010), the species of focus in the present study.

Gossypium mustelinum is one of five allotetraploids of this genus, which includes the cultivated cotton plants ( $G$. hirsutum and G. barbadense). The species is a native of Brazil and endemic to the northeast region, primarily found in the biome of Caatinga (Pickersgill et al., 1975; Barroso et al., 2010). There are no crops found within its area of incidence; however, there is a potential for expansion of the cultivated cotton areas in surrounding areas (Brazilian Native and Naturalized Cotton [ALBRANA], 2013). There are small foci of coexistence with cultivated cotton. They result from maintenance of plants in backyards and from propagule dispersal between producing and consuming regions, with no observed impact on wild populations (Alves et al., 2013). This is an indication that impacts may depend on broader sympatry, where a greater number of cultivated individuals are within the vicinity.

Pathogens that infect commercial crops can also cause diseases in other species of allotetraploid cotton plants, due to their phylogenetic proximity (Gilbert \& Webb, 2007). Thus, the introduction and spread of pathogens from commercial cotton farms may be a threat to the conservation of G. mustelinum populations. The main diseases affecting commercial cotton crops in Brazil are cotton blue disease, caused by the Polerovirus Cotton leafroll dwarf virus - CLRDV; angular leaf spot or blight, caused by the bacterium Xanthomonas citri subsp. malvacearum; ramulose, caused by the fungus Colletotrichum gossypii var. cephalosporioides; root-knot disease, caused by the nematode Meloidogyne incognita; and gray mildew disease, caused by the fungus Ramularia areola (Suassuna \& Coutinho, 2011). Historically, phytosanitary problems with these diseases increased with the expansion and intensification of cotton production in the region. Although one cannot deny the economic and social benefits of cotton production in Brazil, which is the fifth largest cotton producer in the world, its cultivation should not occur at the expense of in situ conservation and maintenance of important native genetic resources.

Although collection and sampling expeditions for ex situ conservation of populations of interest have been conducted, in situ conservation should not be excluded. In situ conservation allows continuity of the evolutionary process of populations, deriving new variations, which may be introduced to germplasm banks (Negri \& Tiranti, 2010). Both methods are complementary and are more efficient for the conservation of total genetic diversity when used together (Sun et al., 2012). In regards to G. mustelinum, efforts have been made to employ both methods (Barroso et al., 2010). Therefore, knowledge of the genetic resistance of G. mustelinum to the major cotton crop diseases may help us to understand the scale of threats to its conservation. In the present study, the resistance of $G$. mustelinum populations to major cotton diseases in Brazil was measured.

\section{Materials and Methods}

\subsection{Plant Material}

Gossypium mustelinum cotton plants were collected in the tributaries of the Contas river basin in the State of Bahia, Brazil. These plants were located in four tributaries: Jacaré Creek, Quixaba Creek, Serra Azul Creek and Riachão Creek. A total of 205 plants were used in this study.

In the resistance evaluation tests (phenotyping), seeds collected in situ from populations of Jacaré Creek (24 plants), Serra Azul Creek (23 plants) and three tributaries of the Riachão Creek I (22 plants), II (22 plants) and III (20 plants) were separated into different treatment groups. Controls for cotton blue disease included the genotypes Delta Opal (G. hirsutum - resistant) and FM 966 (G. hirsutum - susceptible); for angular leaf spot, Delta Opal (resistant) and PA 0435 (G. barbadense - susceptible) and for ramulose, PA 0435 (moderately resistant) and BRS Cedro (G. hirsutum - susceptible).

\subsection{Preparation of Inoculum, Inoculation and Evaluation of Incidence/Severity}

Assessment for angular leaf spot and common mosaic was conducted under field conditions in a randomized block design with five replications, and each plot was comprised of two rows of three meters with one plant per meter. For angular leaf spot, artificial inoculations were made. The inoculum was obtained from Xam isolates previously identified as race 18 cultured in $523 \mathrm{KADO}$ medium for 48 hours and diluted with saline solution $(0.85 \% \mathrm{NaCl})$, and adjusted to 0.3 optical density at $600 \mathrm{~nm}$ absorbance, which corresponds to $10^{8} \mathrm{CFU}$ (Colony Forming Units). 
Inoculation was performed using the syringe method, in which approximately $1.0 \mathrm{~mL}$ of bacterial suspension was injected under pressure at three different points on the abaxial surface of three leaves of each plant. Evaluation was performed 48 hours after inoculation by observing for the presence or absence of anasarca symptoms at the inoculation points. The same test was used to evaluate, via natural infection, the resistance to common mosaic disease caused by whitefly-transmitted geminivirus.

Assessment of cotton blue disease was carried out in a protected screenhouse. The trial was conducted in a randomized block design with five replications, with an experimental unit consisting of one plant grown in soil from the base of the screenhouse. All plants were inoculated using viruliferous aphids (Aphis gossypii) collected from previously cultivated cotton plants with typical cotton blue disease symptoms (inoculum source plant). The inoculations were performed in the different treatments at 20,27 and 34 days after plant emergence (DAE). At each inoculation time, at least five viruliferous aphids, maintained in the inoculum source plants, were transferred to different treatment plants. Disease assessment was qualitatively performed (with or without symptom development) 30 and 60 days after the first inoculation.

Assessment of ramulose resistance was measured in an experiment conducted in a greenhouse. The experiment was conducted in a randomized block design with five replications, and the experimental unit consisted of one plant grown in a pot (20 liters). Three monosporic isolates of the pathogen were previously multiplied in potato dextrose agar (PDA) medium and maintained in a biochemical oxygen demand (BOD) incubator $\left(25^{\circ} \mathrm{C}\right.$ and 12 hours light) for 30 days. A spore suspension at a concentration of $5 \times 10^{5}$ spores $/ \mathrm{mL}$ was prepared. At 30 and 37 DAE, plants were inoculated with the aid of a hand sprayer. Each pot was covered for $24 \mathrm{~h}$ with a plastic bag (100 liter volume) forming a humid chamber. After removal from the humid chamber, the environment was maintained with relative air humidity above $80 \%$ with the aid of microsprinklers that sprayed a mist for 1 minute every 3 hours. Thirty days after the second inoculation, a severity assessment was conducted using a scale from 1 to 5 , with which the disease index was calculated (Oliveira et al., 2010). Due to the inadequate normal distribution of the data, the pair-to-pair difference between treatments for ramulose severity obtained from the average scores was tested using the nonparametric Mann-Whitney test.

\subsection{Genotyping With Microsatellite Markers}

All collected G. mustelinum plants $(\mathrm{n}=205)$ were genotyped using microsatellite markers linked to resistance genes (Table 1). Three G. hirsutum cultivars were used as controls for the presence of resistance alleles: Delta Opal, resistant to cotton blue disease and angular leaf spot; M315, resistant to root-knot nematode; and FM 966, resistant to angular leaf spot and susceptible to cotton blue disease and root-knot nematode.

Five simple sequence repeat (SSR) primer pairs labeled with fluorochromes were used for genotyping. These SSR loci are physically linked to genes that confer resistance to major cotton diseases: DC20027, linked to the Rghv1 gene that confers resistance to cotton blue disease (Fang et al., 2010); CIR246, linked to the B12 gene, which confers resistance to angular leaf spot (Xiao et al., 2010); and CIR316M (Shen et al., 2006) and BNL3661 (Guitiérrez et al., 2010), which are associated with two different loci that control root-knot nematode tolerance. Polymerase chain reactions were performed in a tetraplex system using the Multiplex PCR Kit (Qiagen). Electrophoresis of amplified fragments was performed on an ABI3100 DNA analyzer (Applied Biosystems). Fragment size (bp) was estimated using GeneScan 2.1 with ROX500 and edited with the aid of GeneMapper 3.5 software (Applied Biosystems). SSR marker-assisted analysis in G. mustelinum was carried out by comparing the amplified alleles to the loci of the SSRs that were associated with resistance genes in G. hirsutum.

Table 1. Statistical significance matrix between populations of G. mustelinum (Jacaré Creek, Serra Azul Creek, Riachão Creek I, II, III) and controls (BRS Cedro - susceptible and PA 0435 - moderately resistant)

\begin{tabular}{lllllll}
\hline & Jac & SA & RRI & RRII & RRIII & PA 0435 \\
\hline SA & 0.47 & & & & & \\
RRI & 0.38 & 0.45 & & & & \\
RRII & 0.50 & 0.60 & 0.73 & & & \\
RRIII & 0.79 & 0.76 & 0.31 & 0.38 & & \\
PA 0435 & 0.94 & 0.94 & 0.50 & 0.60 & 0.80 & \\
BRS Cedro & $0.03 *$ & $0.04 *$ & $0.02 *$ & $0.01 *$ & $0.05^{*}$ & $0.04 *$ \\
\hline
\end{tabular}

Mann-Whitney test $(0.05 \%)$. 


\section{Results}
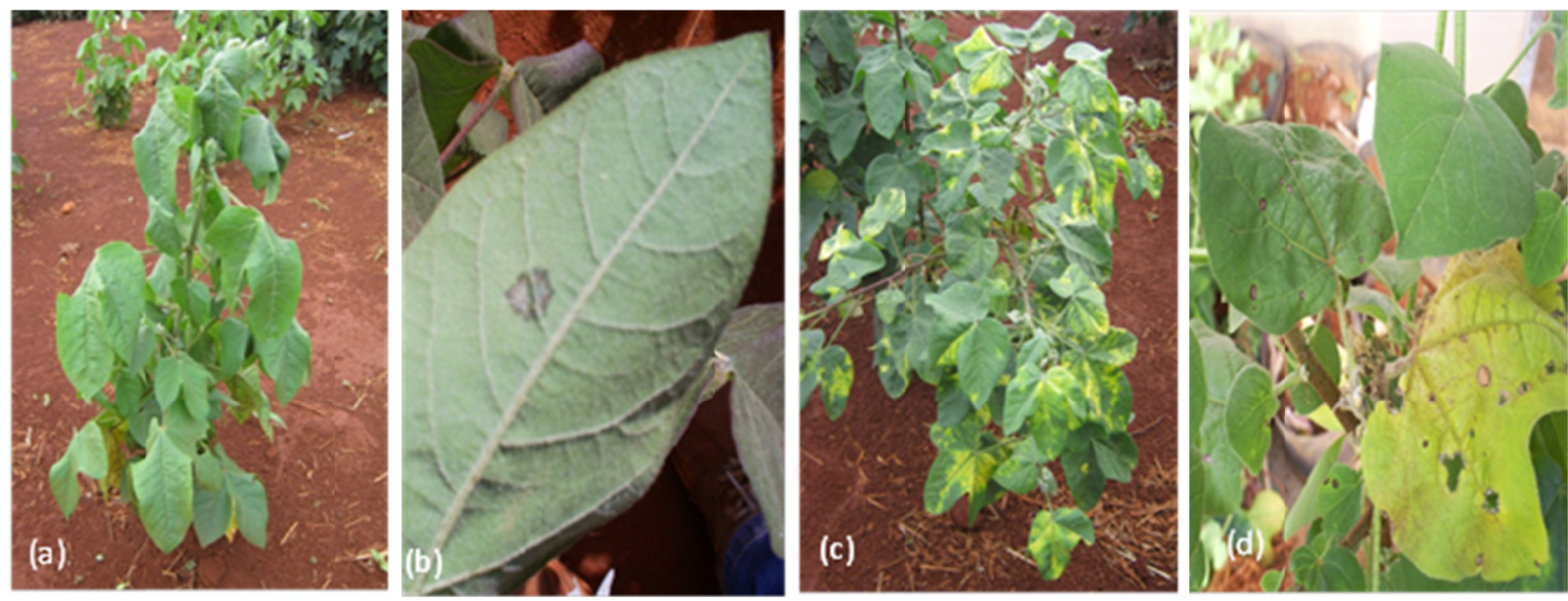

Figure 1. G. mustelinum plants with symptoms of foliar diseases. (a) cotton blue disease, (b) angular leaf spot, (c) common mosaic and (d) ramulose

In the assessment of cotton blue disease, it was observed that only the Delta Opal cultivar did not develop symptoms of viral disease. All G. mustelinum plants and the susceptible control (FM 966) showed typical symptoms of the disease (stunting, leaf rolling and yellowing of veins) (Figure 1a). The severity of symptoms observed in G. mustelinum was similar to that observed in plants of the susceptible G. hirsutum cultivar, with reduced height of plants and inhibited formation of the reproductive structures.

All populations of G. mustelinum developed symptoms of angular leaf spot at the inoculation points. Lesions that initially had a soaked appearance later became brown (Figure 1b). Symptoms were identical to those observed in susceptible controls and different from resistant plants, in which dry and well-defined lesions that were typical of hypersensitivity were formed. Although not artificially inoculated, due to the high pressure of whitefly (Bemisia tabaci), it was possible to quantify the incidence of plants with common mosaic symptoms, a virosis transmitted by this insect and caused by the Abutilon mosaic geminivirus (Figure 1c). All populations of G. mustelinum were susceptible to common mosaic of cotton. Because the inoculation occurred in an uncontrolled manner, plants that had no contact with the virulent insects did not develop symptoms of the virosis. Common mosaic occurrence ranged between 10 and $25 \%$ of plants in all treatments. The same incidence levels were also observed in commercial crops of susceptible cultivars, and the asymptomatic plants represent escaped plants.

All populations of G. mustelinum developed initial symptoms of ramulose (rounded and necrotic leaf spots), especially in younger leaves (Figure 1d). However, disease progression was not as dramatic as in G. hirsutum. After death of the apical meristems, which led to loss of dominance and favored the formation of lateral shoots, there was no development of disease symptoms in secondary branches which had normal vegetative growth. The moderate resistance control, G. barbadense, and all treated G. mustelinum plants had scores ranging from 2 to 4 . On average, the score index attributed to the disease for G. mustelinum populations ranged from 2.6 to 3.0. Significant differences in severity were observed only in the comparison of G. mustelinum populations with the susceptible control (BRS Cedro), with statistical significance of $\mathrm{P}=0.03$ (Jacaré), $\mathrm{P}=0.04$ (Serra Azul), $\mathrm{P}=0.02$ (Riachão I), $\mathrm{P}=0.01$ (Riachão II) and $\mathrm{P}=0.05$ (Riachão III). There was no significant difference between the populations of G. mustelinum and the moderately resistant control (Table 1).

Primers for five SSR loci linked to disease resistance genes in G. hirsutum amplified SSR fragments in G. mustelinum (Table 2). The allelic composition of each locus analyzed was determined in populations of $G$. mustelinum and the control cultivars. The primer DC20027 amplified two loci, a monomorphic (DC20027-1) 182 bp fragment present in all accessions and cultivars, as described by Fang et al. (2010). The locus linked to the resistance gene $(R g h v 1)$ for cotton blue disease was polymorphic, in which four SSR alleles were detected: 202, 200, 196 and $198 \mathrm{bp}$. The $200 \mathrm{bp}$ fragment was present in only one individual of the Jacaré population and was the same allele found in G. barbadense accessions and in disease-susceptible cultivars. Two alleles present in $G$. mustelinum have not yet been observed in G. hirsutum, with sizes of 196 and $198 \mathrm{bp}$. The $196 \mathrm{bp}$ allele appeared more frequently in all populations, being constant in the Jacaré population and with the lowest frequency in the Riachão Creek population. 
Table 2. Composition and allele frequency of SSR loci linked to disease resistance genes in populations of $G$. mustelinum (Jacaré Creek, Quixaba Creek, Serra Azul Creek, Riachão Creek I, II, III) collected in the basin of the Contas River, Bahia and of controls (G. hirsutum)

\begin{tabular}{|c|c|c|c|c|c|c|c|c|c|c|}
\hline \multirow{2}{*}{ Primer } & \multirow{2}{*}{ Allele } & \multicolumn{7}{|c|}{ Population of G. mustelinum } & \multicolumn{2}{|c|}{ G. hirsutum } \\
\hline & & $\mathrm{Jac}$ & Qx & S. A. & RRI & RRII & RRIII & Delta & FM 966 & M315 \\
\hline \multirow{5}{*}{ DC20027 } & 182 & 1.000 & 1.000 & 1.000 & 1.000 & 1.000 & 1.000 & - & - & - \\
\hline & 196 & 0.880 & 1.000 & 0.984 & 0.588 & 0.588 & 0.588 & - & - & - \\
\hline & 198 & 0.080 & - & 0.016 & 0.412 & 0.412 & 0.412 & - & - & - \\
\hline & 200 & 0.040 & - & - & - & - & - & - & 1.000 & 1.000 \\
\hline & 202 & - & - & - & - & - & - & 1.000 & - & - \\
\hline \multirow{3}{*}{ CIR246 } & 146 & - & - & - & - & - & - & 1.000 & 1.000 & 1.000 \\
\hline & 154 & 0.020 & 0.976 & 1.000 & 0.440 & 0.440 & 0.440 & - & - & - \\
\hline & 156 & 0.980 & 0.024 & - & 0.560 & 0.560 & 0.560 & - & - & - \\
\hline \multirow{5}{*}{ CIR316M } & 193 & 0.021 & - & - & - & - & - & - & - & - \\
\hline & 198 & - & - & - & - & - & - & 1.000 & 1.000 & - \\
\hline & 201 & - & - & - & - & - & - & 1.000 & 1.000 & 1.000 \\
\hline & 206 & 0.979 & 1.000 & 1.000 & 1.000 & 1.000 & 1.000 & - & - & - \\
\hline & 210 & - & - & - & - & - & - & - & - & 1.000 \\
\hline \multirow{8}{*}{ BNL3661 } & 183 & 0.091 & 1.000 & 1.000 & 1.000 & 1.000 & 1.000 & - & - & - \\
\hline & 185 & - & - & - & - & - & - & - & - & 1.000 \\
\hline & 189 & 0.909 & - & - & - & - & - & - & - & 1.000 \\
\hline & 195 & 1.000 & - & - & 0.709 & 0.709 & 0.709 & 1.000 & 1.000 & - \\
\hline & 199 & - & 1.000 & 0.170 & 0.013 & 0.013 & 0.013 & - & - & - \\
\hline & 201 & - & - & - & 0.278 & 0.278 & 0.278 & - & - & - \\
\hline & 203 & - & - & 0.542 & - & - & - & - & - & - \\
\hline & 205 & - & - & 0.288 & - & - & - & - & - & - \\
\hline
\end{tabular}

A 156 bp allele amplified with the CIR246 primer was common in G. hirsutum and in G. mustelinum. This allele is associated with susceptibility to race 18 of $X$. citri subsp. malvacearum. In addition to this allele, another allele of $154 \mathrm{bp}$ was also observed in only G. mustelinum. The resistance-associated allele of $146 \mathrm{bp}$ in G. hirsutum was not observed in any of the wild individuals.

Primers CIR316M and BNL 3661, used for marker-assisted selection in G. hirsutum, amplified two loci each. All of these loci were polymorphic in G. mustelinum, except for the CIR316M_201 bp locus present in all accessions used in the present study. The CIR316M_206 bp allele belongs to the same locus described by Wang, Ulloa, and Roberts (2006); however, it differs from the CIR316M_210 bp allele, which is linked to QTL that confer increased tolerance to the root-knot nematode. This allele was observed only in G. mustelinum in homozygous condition in all individuals of all populations except for an individual of the Jacare population, which showed a $193 \mathrm{bp}$ allele. This allele was also amplified in accessions of G. barbadense.

The highest number of alleles was observed for the primer BNL3661. The QTL-associated with root-knot nematode tolerance in wild species showed two SSR alleles of 183 and $189 \mathrm{bp}$ that were not observed in $G$. hirsutum. The first was observed in all subjects of the Quixaba, Serra Azul and Riachão Creek populations, and the second was observed at high frequency in the Jacaré population (Table 2). This primer also amplified a second locus with four SSR alleles, of which only the BNL3661_195 allele was present in cultivars of G. hirsutum classified as susceptible. Therefore, based on the absence in G. mustelinum of SSR alleles of the CIR316M and BNL3661 loci and their presence in resistant cultivars of G. hirsutum (201/210 bp and 185/189 bp, respectively), the root-knot nematode resistance conferred by these alleles was not expected to be present in the wild populations of this study. 


\section{Discussion}

In environments with no or few signs of degradation, G. mustelinum has good multiplication and dissemination capacity (Barroso et al., 2010). The species mainly inhabits areas with longer water availability within the semiarid region in which it occurs, such as the banks of rivers and ponds. However, anthropogenic factors cause damage to the population, particularly the clearing of riparian vegetation which is usually associated with use as a pasture for cattle and goats (Alves et al., 2013). In addition, the commercial cultivation of cotton in close proximity to natural populations can introduce new problems. A likely problem would be related to phytosanitary issues, such as diseases. As reviewed by Gilbert et al. (2002), the introduction of new pathogens or increased inoculum pressure from those that already exist, arising from multiplication in commercial areas, can compromise the local survival of native plant species.

There was no detectable genetic resistance in G. mustelinum for the major diseases that usually affect cotton cultivars in Brazil. The plants of this species showed symptoms similar to those observed in susceptible cultivars for all diseases tested. Therefore, it is likely that the damage caused will also be similar. With angular leaf spot, the disease causes reduced plant vigor and productivity, with loss rates ranging from $20-70 \%$ in susceptible cultivars (Hillocks, 2010). Moreover, the bacteria are able to lodge inside the seed and cause death of the seedlings. Plants from infected seeds that do not suffer tipping serve as a source of bacterial inoculum to healthy plants. Therefore, the ability to produce offspring is reduced.

Plants of the tested populations of G. mustelinum, when inoculated with CLRDV, developed cotton blue disease symptoms similar to susceptible plants of G. hirsutum. Infected plants had reduced development, and when the infection occurred in the early stages of the vegetative phase, it did not produce flowers. When infected after the onset of flowering, the reproductive structures were smaller than those of healthy plants. This reduction in seed production under controlled conditions is indicative of reduced adaptability under field conditions because the multiplication of individuals would be affected dramatically once the disease is introduced in natural populations of G. mustelinum.

The average ramulose severity in G. mustelinum was lower than the average of the susceptible control. This reduced severity might be due to the less effective genes present in this species. However, although noticeable, the level of resistance is very low and the plants still develop symptoms of the disease despite later vegetative recovery. Similar to angular leaf spot, ramulose reduces plant productivity, and the pathogen houses in the seed, causing seedling damping-off and serving as a source of inoculum.

There may be damage to natural populations in the event of introduction or increased incidence of diseases that are common in cotton crops in Brazil. The damage will be proportional to the amount of disease in the populations. If there is increased frequency of a pathogen, natural plant populations may develop the disease and have reduced reproductive capacity and competitive performance with other species present in the habitat. Therefore, diseases pose a real threat to in situ maintenance of existing variability in G. mustelinum.

One of the most likely ways of introducing diseases within populations is the cultivation of cotton in regions where wild species occur. By 2011, cotton crops in the two microregions where the populations under study were present (Vitória da Conquista and Jequié) occupied only 255 ha (Brazilian Institute of Geography and Statistics [IBGE], 2011). This low value, when associated with the lack of cotton crops in nearby populations, suggested that it is unlikely to have negative interferences with materials cultivated in natural populations. In fact, except for common mosaic found in only one plant, none of the other diseases were observed in the field during collection expeditions or on subsequent visits, indicating that there was little or no in situ inoculum pressure. Also during the field visits, the presence of the vector for cotton blue disease virus (Aphis gossypii) was observed; however, the G. mustelinum plants showed no disease symptoms. It is possible that the commercial cultivation of cotton contributes to increase the population of viral vector insects, such as whiteflies and aphids, which may introduce or increase virus transmission capacity, as observed in other plant species (Alexander, 2010; Malmstrom et al., 2005).

The introduction of commercial cultivation of cotton plants in places where there is high native variability must be carefully considered. Due to the low diversity and high inbreeding within populations of the species (Barroso et al., 2010; Alves et al., 2013), the introduction of new pathogens for which there is no genetic resistance would jeopardize the survival of wild genotypes and increase the genetic bottleneck effect found in the species. From the point of view of conservation, the importance of wild cotton should not be neglected, hitherto little known as a genetic resource. Furthermore, it is possible that resistance gene are present at low frequency in the populations and that they have not been verified due to the sampling process.

The SSR loci linked to disease resistance genes in commercial cultivars amplified an allelic composition distinct in wild relatives, making them useful tools for rapid identification of introgression of resistance alleles in natural 
populations of G. mustelinum.

Preventive strategies for the conservation of natural populations are increasingly necessary because small populations present in the basin of the Contas River do not have sources of resistance to any of the pathogens studied. The response to susceptibility may lead to a decrease in seed production. Thus, the path of the persistence of natural populations of G. mustelinum is uncertain, considering the low genetic diversity within the populations. Therefore, collection measures for ex situ conservation, periodic monitoring and continuous review of exclusion zones in view of the discovery of new wild populations are necessary to reduce the threat of loss of diversity as well as the uncertainty of its continuity.

\section{Conclusion}

- G. mustelinum populations collected in the basin of the Contas River were susceptible to cotton blue disease, angular leaf spot, common mosaic and ramulose.

- Primers for SSR loci linked to disease resistance genes in commercial cotton cultivars amplified distinct allelic compositions in wild relatives, making them as useful tools for rapid identification of introgression of resistance alleles in natural populations of G. mustelinum.

- There is a phytosanitary risk arising from the introduction of cotton crops (G. hirsutum) near natural populations of G. mustelinum, which may result in the reduction of these populations due to a likely increase in the incidence and severity of the diseases studied.

\section{Acknowledgments}

Thanks to the Brazilian Agricultural Research Corporation (Empresa Brasileira de Pesquisa Agropecuária EMBRAPA) for financial research support. Thanks to the Coordination for the Improvement of Higher Education Personnel (Coordenação de Aperfeiçoamento de Pessoal de Nível Superior-CAPES) and to the National Council for Scientific and Technological Development (Conselho Nacional de Desenvolvimento Científico e Tecnológico CNPq) for doctoral and productivity fellowships to I.P.P.M. and F.A.G., respectively.

\section{References}

Albrana. (2013). Brazilian Native and Naturalized Cotton. Retrieved June 13, 2013, from http://www.cnpa.embrapa.br/albrana

Alexandre, H. M. (2010). Disease in natural plant populations, communities, and ecosystems: insights into ecological and evolutionary processes. Plant Disease, 5, 492-502. http://dx.doi.org/10.1094/PDIS-94-5-0492

Alves, M. F., Barroso, P. A. V., Ciampi, A. Y., Hoffmann, L. V., Azevedo, V. C. R., \& Cavalcante, U. (2013). Diversity and genetic structure among subpopulations of Gossypium mustelinum (Malvaceae). Genetic Molecular Research, 12, 597-609. http://dx.doi.org/10.4238/2013.February.27.9

Anderson, P. K., Cunningham, A. A., Patel, N. G., Morales, F. J., Epstein, P. R., \& Daszak, P. (2004). Emerging infectious diseases of plants: pathogen pollution, climate change and agrotechnology drivers. Trends in Ecology and Evolution, 10, 535-544. http://dx.doi.org/10.1016/j.tree.2004.07.021

Barroso, P. A. V., Hoffmann, L. V., Batista, C. E., Freitas, R. B., Alves, M. F., Silva, U. C., \& Andrade, F. P. (2010). In situ conservation and genetic diversity of three populations of Gossypium mustelinum Miers (ex Watt). Genetics Resource and Crop Evolution, 57, 343-349. http://dx.doi.org/10.1007/s10722-009-9472-9

Brondani, R. P. V., Zucchi, M. I., Brondani, C., Rangel, P. H. N., Borba, T. C. O., Rangel, P. N., ... Vencovsky, R. (2005). Genetic structure of wild rice Oryza glumaepatula populations in three Brazilian biomes using microsatellite markers. Genetica, 125, 115-123. http://dx.doi.org/10.1007/s10709-005-4916-4

Burle, M. L., Fonseca, R. F., Kami, J. A., \& Gepts, P. (2010). Microsatellite and genetic structure among common bean (Phaseolus vulgaris L.) landraces in Brazil, a secondary center of diversity. Theoretical and Applied Genetics, 121, 801-813. http://dx.doi.org/10.1007/s00122-010-1350-5

Carvalho, V. P., Ruas, P. M., Ruas, C. F., Ferreira, J. M., \& Moreira, R. M. P. (2002). Assessment of genetic diversity in maize (Zea mays L.) landraces using inter simple sequence repeat (ISSR) markers. Crop Breeding and Applied Biotechnology, 4, 557-568. Retrieved from http://www.sbmp.org.br/cbab/siscbab/uploads/c8128f42-566c-e4be.pdf 
Cervi, A. C. (2006). O gênero Passiflora L. (Passifloraceae) no Brasil, espécies descritas após o ano de 1950. Adumbrationes ad Summae Editionem, 16, 1-5. Retrieved June 9, 2013, from http://bibdigital.rjb.csic.es/PDF/Adumb_16.pdf

Darmency, H. (1994). The impact of hybrids between genetically modified crop plants and their related species: $\begin{array}{llll}\text { introgression and } \quad \text { alecular } & \text { Ecology, } & 3, & \text { 37-40. }\end{array}$ http://dx.doi.org/10.1111/j.1365-294X.1994.tb00040.x

Ellstrand, N. C., Prentice, H. C., \& Hancock, J. F. (1999). Gene flow and introgression from domesticated plants into their wild relatives. Annual Review of Ecology and Systematics, 30, 539-63. http://dx.doi.org/10.1146/annurev.ecolsys.30.1.539

Fang, D. D., Xiao, J., Canci, P. C., \& Cantrell, R. G. (2010). A new SNP haplotype associated with blue disease resistance gene in cotton (Gossypium hirsutum L.). Theoretical and Applied Genetics, 120, 943-953. http://dx.doi.org/10.1007/s00122-009-1223-y

Fisher, M. C., Henk, D. A., Briggs, C. J., Brownstein, J. S., Madoff, L. C., \& McCraw, S. L. (2012). Emerging fungal threats to animal, plant and ecosystem health. Nature, 484, 186-194. http://dx.doi.org/10.1038/nature10947

Fukuda, W. M. G., Cavalcanti, J., Fukuda, C., \& Costa, I. R. S. (2005). Variabilidade genética e melhoramento da mandioca (Manihot esculenta Crantz). Recursos Genéticos e Melhoramento de Plantas para o Nordeste Brasileiro. Retrieved from http://www.cpatsa.embrapa.br/catalogo/livrorg/mandioca.pdf

Gilbert, G. S. (2002). Evolutionary ecology of plant diseases in natural ecosystems. Annual Review of Phytopathology, 40, 13-43. http://dx.doi.org/10.1146/annurev.phyto.40.021202.110417

Gilbert, G. S., \& Webb, C. O. (2007). Phylogenetic signal in plant pathogen-host range. Proceedings of the National Academy of Sciences, 104, 4079-4983. http://dx.doi.org/10.1073/pnas.0607968104

Groot, M. H. M., Wiel, C. C. M., Tienderen, P. H., \& Nijs, H. C. M. (2003). Hybridization and introgression between crops and wild relatives. University of Amstersdam \& Plant Research International. 55p. Retrieved from http://www.postbus5100.compleet-en-actueel.nl/pdf/27428k47b3.pdf

Guitiérrez, O. A., Jenkins, J. N., McCarty, J. C., Wubben, M. J., Hayesn, R. W., \& Callahan, F. E. (2010). SSR markers closely associated with genes for resistance to root-knot nematode on chromosomes 11 and 14 of Upland cotton. Theoretical and Applied Genetics, 121, 1323-37. http://dx.doi.org/10.1007/s00122-010-1391-9

Hillocks, R. J. (2010). Cotton diseases and their control in the $21^{\circ}$ century. In P. J. Wakelyn \& M. R. Chaudhry, (Eds), Cotton: Technology for the 21st century. International Cotton Advisory Committee (pp. 155-180).

Ibge. (2011). Brazilian Institute of Geography and Statistics (Instituto Brasileiro de Geografia e Estatística). Retrieved October 26, 2013, from http://www.sidra.ibge.gov.br/bda/tabela/listabl.asp?c $=1612 \& z=\& o=$

Malmstrom, C. M., McCullough, A. J., Johnson, H. A., Newton, L. A., \& Borer, E. T. (2005). Invasive annual grasses indirectly increase virus incidence in California native perennial bunchgrasses. Oecologia, 145, 153-164. http://dx.doi.org/10.1007/s00442-005-0099-z

Menezes, I. P. P., Barroso, P. A. V., Hoffmann, L. V., Lucena, V. S., \& Giband, M. (2010). Genetic diversity of mocó cotton (Gossypium hirsutum race marie-galante) from the northeast of Brazil: implications for conservation. Botany, 88, 765-773. http://dx.doi.org/ 10.1139/B10-045

Negri, V., \& Tiranti, B. (2010). Effectiveness of in situ and ex situ conservation of crop diversity. What a Phaseolus vulgaris L. landrace case study can tell us? Genetica, 138, 985-998. http://dx.doi.org/10.1007/s10709-010-9485-5

Oliveira, M. A. C., Duarte, J. B., Morello, C. L., Suassuna, N. D., \& Oliveira, A. B. (2010). Inheritance of resistance to Colletotrichum gossypii var. cephalosporioides in cotton. Crop Breeding and Applied Biotechnology, $10, \quad 65-73 . \quad$ Retrieved from http://www.sbmp.org.br/cbab/siscbab/uploads/c8eb9793-fabe-8438.pdf

Pickersgill, B., Barrett, S. C. H., \& Lima, A. D. (1975). Wild cotton in northeast Brazil. Biotropica, 7, 42-54. http://dx.doi.org/10.2307/2989799

Shen, X., Becelaere, G. V., Kumar, P., Davis, R. F., May, O. L., \& Chee, P. (2006). QTL mapping for resistance to root-knot nematodes in the M-120 RNR Upland cotton line (Gossypium hirsutum L.) of the Auburn 623 
RNR source. Theoretical and Applied Genetics, 113, 1539-1549. http://dx.doi.org/10.1007/s00122-006-0401-4

Suassuna, N. D., \& Coutinho, W. M. (2011). Manejo das principais doenças do algodoeiro no cerrado Brasileiro. In E.C. Freire (Ed.), Algodão no cerrado do Brasil (2th ed., pp. 567-612). ABRAPA, Brasília.

Sun, J. C., Cao, G. L., Ma, J., Chen, Y. F., \& Han, L. Z. (2012). Comparative genetic structure with single-origin pairs of rice (Oryza sativa L.) landraces from in situ and ex situ conservation programs in Yunnan of China using microsatellite markers. Genetics Resource and Crop Evolution, 59, 1611-1623. http://dx.doi.org/10.1007/s10722-011-9786-2

Wang, C., Ulloa, M., \& Roberts, P. A. (2006). Identification and mapping of microsatellite markers linked to a root-knot nematode resistance gene (rkn1) in Acala NemX cotton (Gossypium hirsutum L.). Theoretical and Applied Genetics, 112, 770-777. http://dx.doi.org/10.1007/s00122-005-0183-0

Xiao, J., Fang, D. D., Bhatti, M., Hendrix, B., \& Cantrell, R. (2010). A SNP haplotype associated with a gene resistant to Xanthomonas axonopodis pv. malvacearum in upland cotton (Gossypium hirsutum L.). Molecular Breeding, 25, 593-602. http://dx.doi.org/10.1007/s11032-009-9355-y

\section{Copyrights}

Copyright for this article is retained by the author(s), with first publication rights granted to the journal.

This is an open-access article distributed under the terms and conditions of the Creative Commons Attribution license (http://creativecommons.org/licenses/by/3.0/). 